\title{
(2) Disclosure of Financial Statements: A Study on aße Mobile Telecommunication Companies in Research house Bangladesh
}

\section{Taposh Kumar Neogy}

Assistant Professor (Accounting), Institute of Business Administration (National University), Rajshahi, BANGLADESH

*E-mail for correspondence: neogyais@gmail.com

Received: Nov 02, 2015;

Accepted: Nov 24, 2015;

Published: Apr 19, 2016

Source of Support: Nil

No Conflict of Interest: Declared

\begin{abstract}
Accounting information produced by AIS through preparing the different financial statements of the selected mobile telecommunication companies is used to meet the needs of interested stakeholders for taking effective decision to serve the different purpose. The selected mobile telecommunication companies follow the provision of IASs/BASs and IFRSs/BFRSs for preparing and presenting the different financial statements. The selected mobile telecommunication companies also follow the Companies Act, 1994, the Securities and Exchange Rules 1987 and other applicable laws in Bangladesh. Accounting Information Systems of the selected mobile telecommunication companies collects stores and disseminates data for the purpose of providing meaningful information to the interested users that assist planning, controlling, coordinating, analyzing and taking effective decision. The general purpose of preparing the different financial statements of the selected mobile telecommunication companies is to provide accounting information to the interested users for taking every effective decision making process. Accurate judgments are impossible unless financial statements are clear and understandable by the interested parties. The study focuses the extent of disclosure scores of the income statement and balance sheet items of the selected mobile telecommunication companies over five years from 2008 to 2012. The results show that the average disclosure scores of income statement and balance sheet items are satisfactory and there is significant difference in disclosure scores of income statement and balance sheet items of the selected mobile telecommunication companies during the period under study. The results also show that most of the respondents reveal that the accounting information produced by AIS of the selected mobile telecommunication companies is moderately adequate and informative and there was significant and non significant difference of opinions among the respondents regarding the adequacy and informativeness of accounting information produced by AIS of the selected mobile telecommunication companies.
\end{abstract}

Keywords: Disclosure, Financial Statements, Mobile Telecom Companies, Bangladesh

JEL Classifications Code: M41, F38

\section{INTRODUCTION}

The decision making process has become more complex and complicated in the modern business world. So, the decision making process should be based on correct and relevant information. Management design various plans and their implementations properly for achieving organizational goals with the help of information generated by the Accounting Information Systems because it accumulates data and provide information for the decision makers. Therefore, it can be said undoubtedly that AIS is an authentic and reliable process of generating, getting and gathering crucial and usable accounting information for the interested users that provides the users with a sense of safety and certainty which are important for having a successful transaction. Actually, the management is greatly strengthened with sound AIS by helping the management to know about the kind of debts that are outstanding, the former cash inflows and outflows, about the nature and amount of available assets etc. Moreover, it assists the management to compare the operating results of two different periods which in turn focuses on the profits made on different financial periods and provides the interested users with a clear understanding of profit and loss, expansion of dividends to stockholders, the rate of return on net assets etc. So, it is true that AIS is necessary of every business organization (Kieso, Weygandt and Warfield, 2004). AIS is essential for providing meaningful information to the various interested users because that information is used 
for necessary decision-making purposes. AIS is used to measure the various economic activities and to prepare the different financial statements of any business organization. AIS is a system for providing accounting information to all stakeholders for necessary decision making, which is presented in the different financial statements such as income statement, balance sheet, owners' equity statement and cash flow statement and disseminated in annual reports at the end of every accounting period. Decision making is an important function in running any business organization and a large number of decisions are regularly made by the management. For decision making, AIS provides the essential information regarding the various activities of the business to the management and external parties who use this information to make effective decisions according to their needs. Disclosure means communicating relevant and reliable information for the interested stakeholders to make effective decision making process. Disclosure in financial reporting is the presentation of necessary information related to a business entity to meet the needs of different users. The users group needs accounting information to decide in their respective field of interest. So, a company has to meet the demand of users but it is a difficult task to meet the demand of all users because there are cost constraints. Disclosure is an important variable in any measurement of accounting quality together with such characteristics as measurement method; presentation and timeliness of reporting and can take a number of different forms. Normally disclosure might be considered in relation to the annual report but there are a number of other routes by which company information is communicated (Marston and Robson, 1997). In the corporate sector, accountability and transparency is the slogan of the day. Communication of economic information to the interest groups is assuming greater importance due to increasing control of economic activities by the corporate sector. Adequate disclosure is the most important way by which we can meet the information need of diverse interest groups of nation decision making. Meaningful communication through disclosure in financial statement also ensures transparency and accountability (Akter and Hoque, 1993). One of the most important goals in the preparation of financial statements is to provide sufficient and timely information to the interested users of financial statements. According to the AICPA the objective of AIS is to present transactions and related disclosures in the financial statements properly. Actually AIS provide information through preparing the different financial statements which is needed in decision making. The adequate disclosure of accounting information is essential for taking every effective decision making process. In the absence of adequate disclosure of accounting information, the decision makers cannot make sound decisions. So, the extent of disclosure scores should be accepted level.

\section{OBJective OF THE Study}

The specific objectives of the study are as follows:

- To know the extent of disclosure scores of income statement and balance sheet items of the selected mobile telecommunication companies.

- To examine the opinions of the respondents regarding the adequacy of accounting information produced by AIS of the selected mobile telecommunication companies.

- To examine the opinions of the respondents regarding the informativeness of accounting information produced by AIS of the selected mobile telecommunication companies.

\section{Methodology of the Study}

Research methodology is a way to systematically solve the research problem. The aim of research methodology is to set up the foundation of the statistical analysis. Research methodology consists of different parts such as:

Sample selection: At present time there are six mobile telecommunication companies working in our country such as Grameenphone Limited (GP), Banglalink Digital Communications Limited, Robi Axiata Limited (Robi), Airtel Bangladesh Limited (Airtel), Pacific Bangladesh Telecom Limited (Citycell), and Teletalk Bangladesh Limited (Teletalk). Researcher has selected two mobile telecommunication companies viz GrameenPhone Ltd. (here in after Company \# 1) and Teletalk Bangladesh Limited (here in after Company \# 2) from the population for the purpose of our study. The selection of the companies is based on the facility of data collection. The selection of sample companies is made purposively for exclusive study.

Selection of the period: Researcher has selected a period of study for five years starting from 2008 to 2012. The period of study has been selected on the basis of availability of data collection.

Nature and sources of data: The present study is based on both primary and secondary data. The secondary data have been collected from the audited annual reports of the Grameenphone Ltd. and Teletalk Bangladesh Limited. Primary data are the opinions of the selected respondents and collected from the respondents personally through structured questionnaires.

Preparation of questionnaire: Researcher has prepared close - ended questionnaire in the light of objectives and hypotheses of the study for the selected respondents. Likert five point rating scale has been used in this questionnaire for measuring the opinions of the respondents. The point on the rating scale measured the opinions of the respondents like greatly $=5$, moderately $=4$, slightly $=3$, neutral $=2$ and not $=1$. 
Selection of the respondents: Primary data for the purpose of the present research study have been collected on 195 respondents consisting of 60 chartered accountants (CA), 50 cost and management accountants (CMA), 30 teachers in accounting (Acad.) and 55 security consultants (SC). 200 questionnaires were distributed out of which 195 respondents have given valuable opinions on the questionnaire and the remaining 5 respondents (teachers in accounting) did not return the questionnaire.

Tools of analysis: After obtaining the data from the different sources various statistical tools like mean values, standard deviation, coefficient of variation, $t$ test and Chi-square test have been used to analyze the collected data.

Construction of the index: A disclosure index has been constructed to find out the pattern of disclosure score by the selected mobile telecommunication companies. There are two types of disclosure indices such as weighted index and un-weighted index. Researcher has constructed un-weighted index using dichotomous scale for the purpose of our research study. For constructing un-weighted index researcher has selected sixty three items. Each item of information has been given a score of zero if it is not disclosed and a score of one has been awarded if that item is disclosed by the sleeted mobile telecommunication companies in the audited annual reports. Then the total of raw score is divided by the total number of items and multiplied by one hundred to get the disclosure percentage.

\section{HyPOTHESES OF THE STUDY}

Hypothesis means some assumptions which have to be tested. Based on the objectives of the present research the following null hypotheses have been developed and tested.

Ho1: There is no significant difference in disclosure scores of the selected mobile telecommunication companies regarding the income statement items.

Ho2: There is no significant difference in disclosure scores of the selected mobile telecommunication companies regarding the balance sheet items.

Ноз: There is no significant difference of opinions among the respondents regarding the adequacy of accounting information produced by AIS of the selected mobile telecommunication companies.

Ho4: There is no significant difference of opinions among the respondents regarding the informativeness of accounting information produced by AIS of the selected mobile telecommunication companies.

\section{FINDINGS OF THE STUDY}

At present AIS has a great role in many decisions. AIS refer to recording and reporting business performance of any organization. Internal users and external users are the main users of accounting information produced by AIS and they collect their necessary information in annual reports through financial statements. Success of business depends on efficiency AIS to a great extent and for those AIS is absolutely necessary to all organization including mobile telecommunication companies. Efficient AIS is essential for the selected mobile telecommunication companies for recording of transaction, processing these transactions and finally preparing the different financial statements to the different interested users. Proper AIS is necessary for any organization for improving the quality of accounting information which helps management to perform their various activities and also assist to the external users to take decisions. The AIS of the selected mobile telecommunication companies is fully computerized and it uses accounting software for recording of transactions, processing of these transactions and preparing the different financial statements like income statement, balance sheet, owners' equity statement, cash flow statement and other statements as desired by management.

\section{Financial Statements of the Selected Mobile TELECOMMUNICATION COMPANIES}

Business organizations communicate their financial condition and operating results to the interested users through preparing the different financial statements produced by AIS and these statements are available in the audited annual reports which are published at the end of accounting period. The different financial statements are necessary to the interested stockholders for evaluating the financial conditions of any business organization for taking every decision making process. Accurate judgments are impossible unless financial statements are clear and understandable by the interested parties. The objective of financial statements is to provide financial information regarding the financial performance and the financial position of any organization that assist the users in making economic decisions. According to conceptual framework, the basic elements of financial statements are assets, liabilities, equity, and investments by owners, distributions to owners, comprehensive income, revenues, expenses, gains and losses. The four basic financial statements such as balance sheet, income statement/profit and loss account, statement of changes in equity and cash flow statement including accounting policies and note of the financial statements which contain in the audited annual reports of the selected mobile telecommunication companies are given below: 


\section{Income Statement}

Income statement is the product of AIS. The income statement provides relevant information regarding revenues and expenses of the ongoing operations over a period of time of any business organization. Revenues are inflows and expenses are outflows. Management uses past and current income statement for future planning and decision making. The selected companies follow the provisions of the Companies Act, 1994 for preparing the income statement/profit and loss account. The selected companies show gross profit after deduction of cost of network operations from revenue and show operating revenue after deduction of operating cost from gross profit. The selected companies show profit before tax after deducting nonoperating expenses from operating profit and show profit after tax after deduction tax expenses from profit before tax during the period under study. Revenue consists of traffic revenue, subscription revenue, connection revenue, roaming revenue, interconnection revenue, customer support revenue, SMS and MMS revenue, internet and data revenue, VAS and other revenue, sale of handsets, sale of data card, sale of vehicle tracking systems, infrastructure sharing revenue, commissions, broadband internet revenue, bills pay service, IT service maintenance fee and replacement of SIM cards. Cost of network operating consists of direct cost of revenue, network operation and maintenance expenses, depreciation and amortization, direct cost of hardware revenue, general and administrative expenses, selling and distribution expenses, expenditure for others and provision for bad and doubtful debts. Non-operating income/expense consists of interest on fixed deposits, interest on short term deposit, default interest provision for BTRC and bank charges and commission. Other income/expenses consist of sale of tender document, foreign exchange, commission from education board and others, miscellaneous income and other income from others and gain on disposal of property, plant and equipment. The following discussion clearly presents the disclosure scores of the income statement items in different years of the selected mobile telecommunication companies.

Year wise disclosure scores regarding income statement debit items: Ho1.1: There is no significant difference in disclosure scores of the selected mobile telecommunication companies regarding the income statement debit items.

Table \# 1: Table showing the disclosure scores of income statement debit items

\begin{tabular}{|c|c|c|c|c|}
\hline Year & Company \# 1 (\%) & Company \# 2 (\%) & t values & SL \\
\hline 2008 & 59.38 & 56.25 & & \\
\cline { 1 - 3 } 2009 & 59.38 & 56.25 & & \\
\hline 2010 & 60.94 & 57.81 & \multirow{3}{*}{11.032} & \multirow{2}{*}{0.000} \\
\hline 2011 & 60.94 & 57.81 & & \\
\hline 2012 & 62.50 & 57.81 & & \\
\cline { 1 - 3 } Avg. & 60.63 & 57.19 & & \\
\hline SD & 1.31 & 0.85 & & \\
\hline CV & 2.15 & 1.49 & & \\
\hline
\end{tabular}

Source: Audited Annual Reports of the Selected Mobile Telecommunication Companies
Table 1 shows the year-wise disclosure scores of income statement debit items of the selected mobile telecommunication companies during the period under study. The mean of disclosure scores of income statement debit items of the selected mobile telecommunication companies are $60.63 \%$ and $57.19 \%$ respectively. From the Table it is observed that Company \# 1 disclosed of income statement debit items more than Company \# 2. The standard deviation of income statement debit items of the selected mobile telecommunication companies are 1.31 and 0.85 respectively and the coefficient of variation of income statement debit items of the selected mobile telecommunication companies are 2.15 and 1.49 respectively during the period under study. In order to see whether there is any significant difference in disclosure scores of income statement debit items of the selected mobile telecommunication companies researcher conducted paired sample $t$ test using SPSS. The result shows that $\mathrm{t}$ value is 11.032 which is significant at 0.000 levels. This indicates that there is significant difference in disclosures scores of income statement debit items of the selected mobile telecommunication companies during the period under study. The Table also presents that the average disclosure scores of income statement debit items of the selected mobile telecommunication companies are satisfactory during the period under study.

Year wise disclosure scores regarding income statement credit items: Ho1.2: There is no significant difference in disclosure scores of the selected mobile telecommunication companies regarding the income statement credit items.

Table \# 2: Table showing the disclosure scores of income statement credit items

\begin{tabular}{|c|c|c|c|c|}
\hline Year & Company \# 1 (\%) & Company \# 2 (\%) & t values & SL \\
\hline 2008 & 57.14 & 53.57 & & \\
\hline 2009 & 57.14 & 53.57 & & \\
\cline { 1 - 3 } 2010 & 60.71 & 57.14 & & \\
\cline { 1 - 3 } 2011 & 60.71 & 57.14 & \multirow{2}{*}{0.972} & \\
\cline { 1 - 3 } 2012 & 60.71 & 58.93 & & \\
\cline { 1 - 3 } Avg. & 59.28 & 56.07 & & \\
\cline { 1 - 3 } SD & 1.96 & 2.40 & & \\
\hline CV & 3.30 & 4.27 & & \\
\hline
\end{tabular}

Source: Audited Annual Reports of the Selected Mobile Telecommunication Companies

Table 2 shows the year-wise disclosure scores of income statement credit items of the selected mobile telecommunication companies during the period under study. The mean of disclosure scores of income statement credit items of the selected mobile telecommunication companies are $59.28 \%$ and $56.07 \%$ respectively which have been found during the period under study. The standard deviation of income statement credit items of the selected mobile telecommunication companies are 1.96 and 2.40 and the coefficient of variation of income statement credit items of the selected mobile telecommunication companies are 3.30 and 4.27 respectively during the period under study. This 
means that the value of $\mathrm{SD}$ and $\mathrm{CV}$ in disclosure scores of Company \# 1 over the years under study is in respect of income statement credit items lowest than that of Company \# 2. In order to see whether there is any significant difference in disclosure scores of income statement credit items of the selected mobile telecommunication companies' researcher conducted paired sample $t$ test using SPSS. The result shows that $t$ value is 8.972 which is significant at 0.001 level. This indicates that there is significant difference in disclosure scores of income statement credit items of the selected mobile telecommunication companies during the period under study. From the previous discussion it is apparent that the average disclosure scores of the income statement credit items of the selected mobile telecommunication companies are satisfactory during the period under study.

\section{Balance Sheet}

Balance sheet is one of the most important financial statements and another product of AIS which provides information regarding financial positions and stability of a business organization that help the interested users for taking various investment decisions. Balance sheet presents the assets, property, owner's equity and liabilities of the selected companies and also gives a summary of firm's resources and obligations on a particular date. Management uses balance sheet for taking decision to perform the business activities properly and the external parties use balance sheet to get valuable and relevant information and a clear picture about the solvency of business which help them in different types of decision making relating to investments and others. The selected companies prepare balance sheet in accordance with the related provisions of the Companies Act, 1994.The selected companies also follow the provisions of International Accounting Standard (IAS) /Bangladesh Accounting Standard (BAS) for presentation of the financial statements. The following discussion clearly presents the disclosure scores of the balance sheet items in different years of the selected mobile telecommunication companies.

Year wise disclosure scores of balance sheet assets items:

Ho2.1: There is no significant difference in disclosure scores of the selected mobile telecommunication companies regarding the balance sheet assets items.

Table \# 3: Table showing the disclosure scores of balance sheet assets items

\begin{tabular}{|c|c|c|c|c|}
\hline Year & Company \# 1(\%) & Company \# 2 $(\%)$ & $\mathrm{t}$ values & SL \\
\hline 2008 & 62.35 & 55.29 & & \\
\cline { 1 - 3 } 2009 & 63.53 & 56.76 & & \\
\cline { 1 - 3 } 2010 & 63.53 & 61.18 & \multirow{3}{*}{4.221} & \multirow{3}{*}{0.013} \\
\hline 2011 & 63.53 & 61.18 & & \\
\cline { 1 - 3 } 2012 & 64.71 & 61.18 & & \\
\cline { 1 - 3 } Avg. & 63.53 & 59.12 & & \\
\hline SD & 0.83 & 2.87 & & \\
\hline CV & 1.31 & 4.86 & & \\
\hline
\end{tabular}

Source: Audited Annual Reports of the Selected Mobile Telecommunication Companies
Table 3 shows the year-wise disclosure scores of balance sheet assets items of the selected mobile telecommunication companies during the period under study. The mean of disclosure scores of balance sheet assets items of the selected mobile telecommunication companies are $63.53 \%$ and $59.12 \%$ respectively during the period under study. It is evident that Company \# 1 disclosed of balance sheet assets items more than Company \# 2. The standard deviation of balance sheet assets items of the selected companies are 0.83 and 2.87 and the coefficient of variation of balance sheet assets items of the selected mobile telecommunication companies are 1.31 and 4.86 respectively. This means that the disclosure scores varied over the years under study in respect of balance sheet asset items between the two selected mobile telecommunication companies. In order to see whether there is any significant difference in disclosure scores of balance sheet assets items of the selected mobile telecommunication companies researcher conducted paired sample $t$ test using SPSS. The result shows that $\mathrm{t}$ value is 4.221 which is significant at 0.013 level. This indicates that there is significant difference in disclosure scores of balance sheet assets items of the selected mobile telecommunication companies during the period under study. From the above Table it is apparent that the average disclosure scores of the balance sheet assets items of the selected mobile telecommunication companies are satisfactory during the period under study.

Year wise disclosure scores regarding the balance sheet liabilities items: Ho2.2: There is no significant difference in disclosure scores of the selected mobile telecommunication companies regarding the balance sheet liabilities items.

Table \# 4: Table showing the disclosure scores of the balance sheet liabilities items

\begin{tabular}{|c|c|c|c|c|}
\hline Year & Company \# 1 (\%) & Company \# 2 (\%) & t values & SL \\
\hline 2008 & 58.13 & 54.38 & & \\
\cline { 1 - 3 } 2009 & 58.75 & 54.38 & & \\
\cline { 1 - 3 } 2010 & 58.75 & 56.25 & & \\
\cline { 1 - 3 } 2011 & 60.63 & 56.25 & & \\
\cline { 1 - 3 } 2012 & 60.63 & 56.88 & & \\
\cline { 1 - 3 } Avg. & 59.38 & 55.63 & & \\
SD & 1.17 & 1.17 & & \\
\hline CV & 1.97 & 2.10 & & \\
\hline
\end{tabular}

Source: Audited Annual Reports of the Selected Mobile Telecommunication Companies

Table 4 shows the year-wise disclosure scores of balance sheet liabilities items of the selected mobile telecommunication companies during the period under study. The table shows that the mean of disclosure scores of balance sheet liabilities items of the selected mobile telecommunication companies are 59.38\% and 55.63\% respectively. It is praiseworthy that balance sheet liabilities items have been disclosed more by Company \# 1 than Company \# 2 during the period under study. The standard deviations of balance sheet liabilities items of the selected 
mobile telecommunication companies are same that is 1.17 and 1.17 and the coefficient of variation of balance sheet liabilities items of the selected mobile telecommunication companies are 1.97 and 2.10 respectively during the period under study. In order to see whether there is any significant difference in disclosure scores of balance sheet liabilities items of the selected mobile telecommunication companies researcher conducted paired sample t test using SPSS. The result shows that $t$ value is 10.954 which is significant at 0.000 level. This indicates that there is significant difference in disclosure scores of balance sheet liabilities items of the selected mobile telecommunication companies. The Table also highlights that the disclosure scores of balance sheet liabilities items of the selected mobile telecommunication companies are satisfactory during the period under study.

Statement of Changes in Equity: The statement of changes in owner's equity shows the ending capital which is invested by the owners and changes in equity over the accounting period of any business organization. The owners' equity is increased by the two ways such as investment by the owners and net income from the operation of the business and decrease by the two ways such as withdrawals by the owners and losses from the operation of the business at a specific accounting period. The statement of changes in owners' equity is used to know the amount of starting equity and the amount of their equity at the end of the period. The selected companies prepare statement of change in equity at the end of every accounting period to know the ending equity. The selected companies follow a columnar format which reconciles the opening and closing balances of each element of shareholders' equity. Thus it presented reconciliation between the carrying amounts of share capital, share premium, capital reserve, deposit from shareholders, general reserve at the beginning and end of a particular period, separately disclosing each change. Both the selected companies showed the figures for the two years.

Cash Flow Statement: Cash flow statement is an important financial statement that provides information about the cash receipts and payments and net changes in cash resulting from operating, investing and financing activities of the business organization for a particular period of time. Managers get necessary information about cash inflows for business operations which are used in decision making of different aspects. Cash flow statement also provides information which determines the capacity of company to meet its short term liability. The selected companies present cash flow statement in their annual report of every accounting period. The selected companies follow the provision of International Accounting Standard (IAS)/Bangladesh Accounting Standard (BAS) for preparing and presenting the cash flow statements. The selected companies show net cash used in investing activities and financing activities of the current. The selected companies reconcile with closing cash balance. Capital work in progress consists of acquisition cost of network plant and machinery and capital components and related installation cost till the date of use in network service. The company shows intangible assets at cost less accumulated amortization using the straight-line method. The company settles the inventories using the weighted average method.

Accounting Policies: Accounting policies mean some rules and procedures which are adopted by management and they help in preparing and presenting the financial statements at the end of every accounting period and it assists users to better understand and interpret company financial statements. Accounting policies are essential for presenting the quantity and quality of financial information contained in the financial statements and financial reports. Accounting policies are also necessary for the computation of depreciation, the recognition of capital expenditures and matching of revenues and expenses. In the absence of sufficient accounting policies of the selected companies it will be impossible to interpret the financial statements in a better way and the decision maker would be unable to take sound decisions. The users of different financial statements must be aware of the accounting policies used by organization so that they can better understand the financial statements and make comparisons with the statements of others. Both of the companies provide accounting policies in notes to financial statements under the heading of significant accounting policies according to International Accounting Standard (IAS)/Bangladesh Accounting Standard (BAS). From the analysis of the annual reports of selected companies it is apparent that the companies apply accounting policies consistently in different financial statements in different years.

Notes to the Financial Statements: Notes to financial statements are a vital part of financial statements as they help the interested users know the detailed information regarding items of different financial statements of the selected companies. Sufficient notes are important to know different financial statements as it indicates the inclusion of various items which are important for the better interpretation of the different parts of financial statements. These notes are presented following systematic way in the annual reports. Each of the items like balance sheet, income statement and other include related note in the notes to financial statements section which help the user to understand the included items of the different financial statements. The selected companies present information about their corporate background and nature of the business. They also give information about the basis of preparation of the different financial statements. Necessary notes about the various accounting policies are also given by the selected companies under the heading of significant accounting policies. They place 
information about the estimated useful life of tangible and intangible assets. Note about income tax rate and the amount of income tax expenses are provided by both the companies. They also gather information in the notes to financial statements section about the revenue recognition, measurement and presentation. Information about the direct cost of revenue is also presented by the selected companies. They present information about the cost of SIM cards, scratch card and handset. They present information that includes the network operation and maintenance expenses, general and administrative expenses and selling and distribution expenses. The above information is necessary to determine the profit or loss of the companies on study. The selected companies give information about the depreciation and amortization. Information about the bad debt expenses, provision for bad debts and recovery of bad debts are presented by the selected companies. Gain or loss of foreign exchange, categories of receivable are presented by them. Their balance sheet includes information about the advances deposits and prepayments, cash and cash equivalents. Information related with provision, trade and other payables have been stated by them.

Researcher made an opinion survey of the respondents regarding the adequacy and informativeness of accounting information produced by Accounting Information Systems of the selected mobile telecommunication companies. These factors are related with the extent of disclosure and in this section the opinions of the respondents regarding the adequacy and informativeness of accounting information have analyzed. In order to see whether there is any significant difference of opinions among the respondents regarding the adequacy and informativeness of accounting information produced by AIS of the selected mobile telecommunication companies, researcher developed null hypotheses and conducted Chi-square test to test the null hypotheses. The following hypothesis has been developed to test the degree of adequacy of accounting information produced by AIS of the selected mobile telecommunication companies.

Hoз: There is no significant difference of opinions among the respondents regarding the adequacy of accounting information produced by AIS of the selected mobile telecommunication companies.

Table \# 5: Table showing the opinions of the respondents regarding the adequacy of accounting information produced by AIS of the selected mobile telecommunication companies

\begin{tabular}{|c|c|c|c|c|c|c|c|c|c|c|c|c|}
\hline \multirow{3}{*}{ Types of Opinions } & \multicolumn{8}{|c|}{ Respondent Groups } & \multirow{2}{*}{\multicolumn{2}{|c|}{ Total }} & $x^{2}$ & SL \\
\hline & \multicolumn{2}{|c|}{ CA } & \multicolumn{2}{|c|}{ CMA } & \multicolumn{2}{|c|}{ Acad. } & \multicolumn{2}{|c|}{ SC } & & & \multirow{8}{*}{9.703} & \multirow{8}{*}{0.642} \\
\hline & No. & $\%$ & No. & $\%$ & No. & $\%$ & No. & $\%$ & No. & $\%$ & & \\
\hline Greatly Adequate & 15 & 25.00 & 19 & 38.00 & 08 & 26.67 & 18 & 32.73 & 60 & 30.77 & & \\
\hline Moderately Adequate & 40 & 66.66 & 25 & 50.00 & 16 & 53.34 & 30 & 54.54 & 111 & 56.92 & & \\
\hline Slightly Adequate & 03 & 5.00 & 06 & 12.00 & 04 & 13.33 & 06 & 10.91 & 19 & 9.74 & & \\
\hline Neutral & 01 & 1.67 & 00 & 00 & 01 & 3.33 & 01 & 1.82 & 03 & 1.54 & & \\
\hline Not Adequate & 01 & 1.67 & 00 & 00 & 01 & 3.33 & 00 & 00 & 02 & 1.03 & & \\
\hline Total & 60 & 100 & 50 & 100 & 30 & 100 & 55 & 100 & 195 & 100 & & \\
\hline
\end{tabular}

Source: Opinion Survey
Table \# 5 shows the opinions of the respondents regarding the adequacy of accounting information produced by AIS of the selected mobile telecommunication companies and it is evident that $30.77 \%$ of the respondents think that the accounting information is greatly adequate, $56.92 \%$ of the respondents mention that the accounting information is moderately adequate, $9.74 \%$ of the respondents opine that the accounting information is slightly adequate, $1.54 \%$ of the respondents are neutral and $1.03 \%$ of the respondents opine that the accounting information are not adequate. Majority of the respondents think that the accounting information produced by AIS of the selected companies is moderately adequate. In order to see whether there is any significant difference of opinions among the respondents' regarding the adequacy of accounting information produced by AIS of the selected companies, researcher has conducted $\chi 2$ test. It is found that the value of $\chi 2$ is 9.703 which is significant at 0.642 levels. So, the null hypothesis is accepted which means that there is no significant difference of opinions among the respondents regarding the adequacy of accounting information produced by AIS of the selected mobile telecommunication companies. From the foregoing discussion it is evident that the accounting information produced by AIS and disseminated in annual report is adequate. The following hypothesis has been developed to test the degree of informativness of accounting information produced by AIS of the selected mobile telecommunication companies.

Ho4: There is no significant difference of opinions among the respondents regarding the informativeness of accounting information produced by AIS of the selected mobile telecommunication companies.

Table \# 6: Table showing the opinions of the respondents regarding the informativeness of accounting information produced by AIS of the selected mobile telecommunication companies

\begin{tabular}{|c|c|c|c|c|c|c|c|c|c|c|c|c|}
\hline & \multicolumn{8}{|c|}{ Respondent Groups } & \multirow{2}{*}{\multicolumn{2}{|c|}{ Total }} & $x^{2}$ & SL \\
\hline & \multicolumn{2}{|c|}{$\mathrm{CA}$} & \multicolumn{2}{|c|}{ CMA } & \multicolumn{2}{|c|}{ Acad. } & \multicolumn{2}{|c|}{$\mathrm{SC}$} & & & \multirow{8}{*}{21.262} & \multirow{8}{*}{0.047} \\
\hline Types of Opinions & No. & $\%$ & No. & $\%$ & No. & $\%$ & No. & $\%$ & No. & $\%$ & & \\
\hline Greatly Informative & 14 & 23.33 & 23 & 46.00 & 08 & 26.67 & 19 & 34.54 & 64 & 32.82 & & \\
\hline Moderately Informative & 41 & 68.33 & 22 & 44.00 & 21 & 70.00 & 33 & 60.00 & 117 & 60.00 & & \\
\hline Slightly Informative & 05 & 8.34 & 04 & 8.00 & 00 & 00 & 01 & 1.82 & 10 & 5.13 & & \\
\hline Neutral & 00 & 00 & 01 & 2.00 & 00 & 00 & 02 & 3.64 & 03 & 1.54 & & \\
\hline Not Informative & 00 & 00 & 00 & 00 & 01 & 3.33 & 00 & 00 & 01 & 0.51 & & \\
\hline Total & 60 & 100 & 50 & 100 & 30 & 100 & 55 & 100 & 195 & 100 & & \\
\hline
\end{tabular}

Source: Opinion Survey

Table \# 6 presents the opinions of the respondents regarding the informativeness of accounting information produced by AIS of the selected mobile telecommunication companies and it is found that $32.82 \%$ of the respondents think that the accounting information is greatly informative, $60.00 \%$ of the respondents mention that the accounting information is moderately informative, $5.13 \%$ of the respondents opine that the accounting information is slightly informative, $1.54 \%$ of the respondents are neutral and $0.51 \%$ of the respondents opine that the accounting information is not informative. Majority of the respondents think that the accounting 
information produced by AIS of the selected companies is moderately informative. In order to see whether there is any significant difference of opinions among the respondents' regarding the informativeness of accounting information produced by AIS of the selected companies, researcher has conducted $\chi 2$ test. It is found that the value of $\chi 2$ is 21.262 which is significant at 0.047 levels. So, the null hypothesis is rejected which means that there is significant difference of opinions among the respondents regarding the informativeness of accounting information produced by AIS of the selected mobile telecommunication companies. From the previous discussion it is evident that the respondents are not unanimous the accounting information produced by AIS and disseminated in annual report is informative.

\section{Major Observations}

- The average disclosure scores of income statement debit items of the selected mobile telecommunication companies are $60.63 \%$ and $57.19 \%$ respectively and the null hypothesis is rejected which means that there is significant difference in disclosures scores of income statement debit items of the selected mobile telecommunication companies during the period under study.

- The mean of disclosure scores of income statement credit items of the selected mobile telecommunication companies are 59.28\% and 56.07\% respectively and the null hypothesis is rejected which means that there is significant difference in disclosure scores of income statement credit items of the selected mobile telecommunication companies during the period under study.

- The mean of disclosure scores of balance sheet assets items of the selected mobile telecommunication companies are $63.53 \%$ and $59.12 \%$ respectively and the null hypothesis is rejected which means that there is significant difference in disclosure scores of balance sheet assets items of the selected mobile telecommunication companies during the period under study.

- The mean of disclosure scores of balance sheet liabilities items of the selected mobile telecommunication companies are $59.38 \%$ and $55.63 \%$ respectively and the null hypothesis is rejected which means that there is significant difference in disclosure scores of balance sheet liabilities items of the selected mobile telecommunication companies.

- $56.92 \%$ of the respondents reveal that the accounting information produced by AIS of the selected mobile telecommunication companies is moderately adequate and the null hypothesis is accepted which means that there is no significant difference of opinions among the respondents regarding the adequacy of accounting information produced by AIS of the selected mobile telecommunication companies.
- $60.00 \%$ of the respondents think that the accounting information produced by AIS of the selected mobile telecommunication companies is moderately informative and the null hypothesis is rejected at 0.047 level of significance which indicate that there is significant difference of opinions among the respondents regarding the informativeness of accounting information produced by AIS of the selected mobile telecommunication companies.

\section{CONCLUSION}

The present study highlights that the accounting information produced by AIS through preparing the different financial statements such as income statement, balance sheet, owners' equity statement and cash flow statement is used for taking decision of the interested users. The AIS of selected mobile telecommunication companies also provide various accounting policies, note to the financial statements and various ratios for the interested users so that they can take sound decision on the basis of necessary demand. The interested user group includes investors, consumers, creditors, research scholars, government, tax authority, trade association, stock exchange, members of non-profit organization, owners, employees and managers in different level of management and many one who take their necessary decisions based on the information produced by AIS and shown in the audited annual reports of the selected mobile telecommunication companies. Accounting information helps to the interested users in evaluating the past operations, in controlling the present operations and in deciding the future operations of any business organization. The interested users make various decisions such as financing decision, investment decision, capital structure decision, working capital decision, pricing decision, servicing decision and others necessary decisions with the help of accounting information. The users of accounting information who have different interest always expect credible accounting information from companies. Providing accounting information that is reliable, relevant and transparent to the potential users results in an enhanced investor' confidence. Accounting information produced by AIS of the selected mobile telecommunication companies for the interested users and the users expect that the management publish annual reports at the end of every accounting period that should be certified properly by the professional accountants so that the quality of the accounting information presented in the different financial statements is ensured. Since the various interested users of financial statements are decision oriented so the selected mobile telecommunication companies should ensure the transparency of different financial statements shown in the audited annual reports. The preparation of the different financial statement must be more carefully done and the disclosure scores of accounting information should be more timely and well structured for various interested users so that they can make effective and dynamic decisions. 


\section{REFERENCES}

Abedin MM, Ahmed AA and Neogy TK. 2012. Mechanism of Accountability and Auditing: Public Sector Scenarios of Bangladesh Journal of Business Studies, 4, 131-148.

Ahmed AA and Neogy TK. 2010. Forensic Accounting in Bangladesh: Emergence and Introduction Development Compilation, 3, 71-82.

Ahmed AA, Khan W and Hossain MS. 2011. Reporting Practice of Accounting Disclosure on Changes in Listed Companies of Bangladesh ASA University Review, 5, 83-96.

Ahmed AA. 2009. Measurement and Analysis of the Extent of Timeliness in Corporate Annual Reports of Banking Sector in Bangladesh Development Compilation, 1, 45-56.

Ahmed AA. 2009. The Effect of Timeliness Regulation of Corporate Financial Reporting: Evidence from Banking Sector of Bangladesh Accounting and Management Information Systems, 8, $216-235$.

Ahmed AA. 2012. Disclosure of Financial Reporting and Firm Structure as a Determinant: A Study on the Listed Companies of DSE ASA University Review, 6, 43-60.

Ahmed AA. 2015. Relationship between Foreign Direct Investment and Company Taxation: Case of Bangladesh American Journal of Trade and Policy, 2, 125-129.

Ahmed AA. In: Business Management (https://www.lappublishing.com/), ed. 2012. Compliance of Financial Disclosure: Long Walk to Accounting Research 1 Germany: LAP LAMBERT Academic Publishing.

Akter and Hoque (1993), "Disclosure Practices in Bangladesh: A Case Study of the Banking Sector", Dhaka University Journal of Business Studies, Vol. 14(2), pp. 29-42.

Akter, et.al. (2007), "The effect of the phases of system development life cycle (SDLC) on the performance of Accounting Information System (AIS) development: the Bangladesh scenario", ASA University Review, Vol. 1, No.1 (First issue), July-December.

Alam, et. al., (2007), "Factors Affecting Customer Satisfaction in the Mobile Phone Industry: An Empirical Study in Bangladesh", Journal of Business Administration, Vol. 33, No. 3 \& 4, PP. 43-70.

Audited Annual Reports of Grameenphone Ltd. and Teletalk Bangladesh Limited over five years from 2008 to 2012.

Bairagi, A. K., Roy, T. and Polin, A. (2011),"Socio-Economic Impacts of Mobile Phone in Rural Bangladesh: A Case Study in Batiaghata Thana, Khulna District", IJCIT, Vol. 02, Issue 1, pp. 42-48.

Bangladesh Economic Review, (2006), Economic Adviser's Wing, Finance Division, Ministry of Finance, Government of the People's Republic of Bangladesh.

Begum R, Ahmed AA and Neogy TK. 2012. Management Decisions and Univariate Analysis: Effects on Corporate Governance in Bangladesh Journal of Business Studies, 3, 87-115.

Dey MM and Ahmed AA. 2009. Bank Loan Officers' Perceptions of Corporate Financial Disclosure in the Banking Sector of Bangladesh: An Empirical Analysis Research Paper, 1-8.

Dey, (2007), "Accounting Information System in Commercial Banks - An Evaluation in Bangladesh", the Bangladesh Accountant, pp 80-88.

Haider and Akhter, (2006), "Accounting Information Quality: An Area of Extended Thinking", the Cost and Management, Vol. 34, No. 3, pp. 5-14.

Hossain, et. al, (2008), Financial Performance of GrameenPhone Ltd: An Overview, Islamic University Studies (Part - c), Volume 7, No. 2, June.
Jahan, (1999), “Quality of Information Used in Small Enterprises Marketing Management and Its Impact on Business: A Case Study of Kushtia District”, Islamic University Studies, Part-C, Vol. 2, No. 1, pp. 223-234.

Kam, (1986), "Accounting Theory", John Wiley \& Sons, U.S.A.

Khan, M.Y. and Jain, P.K. (2002), Financial Management, Prentice Hall of India New Delhi.

Kieso, D. E., Weygandt, J. J. and Warfield, T. D. (2004), “Intermediate Accounting", Eleventh Edition, USA, John Willey \& Sons, Inc.

Marston, C. and Robson, P. (1997), "Financial Reporting in India: Changes in Disclosure over the Period 1982 to 1990", AsiaPacific Journal of Accounting, June, pp. 109-140.

Moscove and Simkin (1981), "Accounting Information Systems", John Wiley \& SONS, New York.

Muttakin and Hossain (2003), "Presentation of Financial Statements: A Study of the Listed Cement Companies", the Bangladesh Accountant, pp. 22-32.

Neogy TK and Ahmed AA. 2015. The Extent of Disclosure of Different Components of Disclosure Index: A Study on Commercial Banks in Bangladesh Global Disclosure of Economics and Business, 2, 100-110.

Onaolapo and Odetayo (2012), "Effect of Accounting Information System on Organization Effectiveness: A Case Study of Selected Construction Companies in Ibadan, Nigeria", American Journal of Business and Management, Vol. 1, No. 4, pp. 183-189.

Pandey, I. M., (2007) Financial Management, Vikas Publishing House Pvt. Ltd., Delhi.

Pyle and Larson, (1984), "Fundamental Accounting Principles", Tenth Edition, Richard D. Irwin, Inc., U.S.A

Quader MT, Neogy TK and Ahmed AA. 2010. Econometric Growth Rates Analysis of Basic Bank Limited in Bangladesh: An Evaluation Development Compilation, 4, 48-60.

Ratan, S. R. A., Alam, M. S. and Sohel-Uz-Zaman, A. S. M. (2007), "Innovation Strategy: A Realistic Example in Bangladesh Mobile Telecommunication Service Marketing", The Cost and Management, Vol. 35, No. 1, January-February, pp. 49-58.

Romney and Steinbart, (2006), "Accounting Information Systems", Tenth Edition, Person Education, Inc., U.S.A.

Rouf MA, Hasan MS and Ahmed AA. 2014. Financial Reporting Practices in the Textile Manufacturing Sectors of Bangladesh ABC Journal of Advanced Research, 3, 57-67.

Sajady et. al. (2008), "Evaluation of the Effectiveness of Accounting Information Systems", International Journal of Information Science and Technology, Volume 6, Number 2, pp. 49-59.

Siddiqui and Chowdhury, (2003), "Relevance of Accounting Information in Bangladesh: An Empirical Study", Journal of Business Studies, Vol. XXIV, No. 2, pp. 119-126.

Sori, (2009), "Accounting Information Systems (AIS) and Knowledge Management: A Case Study", American Journal of Scientific Research, Issue 4, pp. 36-44.

Summers, (1989), "Accounting Information Systems", Houghton Mifflin Company, USA

Weygandt, et. al. (1976), "Accounting Principles", John Wiley \& Sons Inc., 6th Ed., New York.

Wilkinson, et. al. (1986), "Accounting and Information Systems", Second Edition, Join Wiley and Sons, Inc., U.S.A

$$
\text { --0-- }
$$




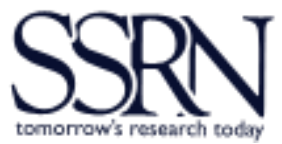

\section{SOCIAL SCIENCE RESEARCH NETWORK 2171 Monroe Avenue, Suite 203, Rochester, NY 14618, USA http://www.ssrn.com/en/}

AJTP Link: http://www.ssrn.com/link/American-Journal-Trade-Policy.html 